\title{
APPROACH TO IMPLEMENTATION \\ OF CONTROLLING SYSTEM AT ENTERPRISES \\ OF THE PORT SECTOR OF UKRAINE
}

\section{Svitlana Oneshko ${ }^{1}$ \\ Mariia Boiko}

DOI: https://doi.org/10.30525/978-9934-588-15-0-41

Abstract. The relevance of the study is due to the processes of reforming at enter-prises of the port sector, which are accompanied by a gradual transition from the public sector to the private that is the interests of development are mainly commercial and aimed at maximizing profits. The main purpose of the research is to justification the introduction of controlling system at enterprises of the port sector and identifies the main stages of its implementation. The subject of the study is feasibility of implementation of a controlling in the enterprise management system. Theoretical and methodological basis of the research is the dialectical method of cognition of socio-economic phenomena in their interconnection, scientific developments of domestic and foreign scientists on issues of expediency of introduction of controlling in the enterprise management system, analytical materials and evaluation of the dynamics of performance results of state port operators of Ukraine. The following methods were used in the work: theoretical synthesis, analysis and synthesis, historical, abstract-logical method, dialectic - in the study of theoretical foundations of the problem under study and in the formulation of conclusions and proposals. Results. The systema-tization of scientific research has shown the need for introduction of controlling in the management system at enterprises of the port sector, due to the following main reasons: increased instability of the environment and the need for continuous tracking and increase the speed of reaction to its changes; the existence of disadvantages in terms of cost-ef-

\footnotetext{
${ }^{1}$ Candidate of Economic Sciences,

Associate Professor of Department of Economics and Finance,

Odesa National Maritime University, Ukraine

${ }^{2}$ Candidate of Economic Sciences,

Junior Researcher of Research Institute of Fundamental and Applied Research,

Odesa National Maritime University, Ukraine
}

(C) Svitlana Oneshko, Mariia Boiko 
fectiveness; significant deterioration of the main productive assets and inefficiency of investments; long distraction from the circulation of financial resources into accounts receivable; lack of tools for selecting relevant information; insufficient internal control and inconsistency of accounting policy with the requirements of the current legislation. The obtained results deepen and develop the conceptual foundations of controlling system at the enterprise and can serve as a basis for further research in this area, in particular, the development of a methodology and tools for assessing the effect of introducing controlling at enterprises of the port sector. The practical significance of the research carried out is that the main theoretical conclusions and methodological provisions are brought to the level of concrete practical recommendations and can be used in the activities of port enterprises to improve the efficiency of functioning.

\section{Introduction}

The formation and development of controlling in Ukraine is rather limited in nature and is used rarely in practice by business entities. Given the slow rate of economic development and the lack of effective tools for strategic and operational control at the enterprise level, the importance of controlling is increasing. This fact is reinforced by arguments in the direction of economic consequences of incorrect management decisions in the form of cash losses.

The relevance of the research is due to the processes of reforming in the port sector, which are accompanied by a gradual transition from the public sector to the private that is the interests of development are mainly commercial: finding the optimal volume of loading and unloading works (LUW), the optimal correlation of cost and tariffs to achieve maximum profits. For a stevedoring company, as a structural element of enterprises of the port sector, such tasks are top priority, and their solution is possible through the introduction of controlling system.

The main purpose of the research is to justify the introduction of controlling system at enterprises of the port sector and identify the main stages of its implementation. To achieve the goal of the following research set forth the following tasks are set: determine the role of the controlling system in the management of the enterprise; formulate the main advantages and disadvantages of introducing controlling in the enterprise; analyze the 
existing practice of introducing controlling in the enterprise; to substantiate the necessity of implementation of the controlling system at the enterprises of the port sector; to identify the problem aspects of the implementation of the controlling system at port enterprises; to propose an organizational and economic approach to the implementation of the controlling system in the work of the stevedoring company.

In the process of studying theoretical aspects of the essence, necessity, problem aspects and practice of implementation of the controlling system, the following methods were used: comparison - to establish differences and common features in the processes and phenomena under study; abstraction - to identify significant factors that are of greatest importance for the study of the process of assessing the use of control system; analysis - to detail the subject of research into its parts; synthesis - for the connection of individual traits of the subject of research into a single whole, the inductive-deductive method - for the synthesis of scientific conclusions based on data collected mainly by direct observation method, as well as methods of analogy, concretization and formalization.

\section{Analysis of recent researches and publications}

The question of the introduction of controlling on the enterprise management system is rather actively being discussed by scientists. Researches on the definition of the essence of controlling, its development, concepts and the mechanism of implementation are presented in the works of V. Becker (Becker, 1990), R. Mann (Mann, 1993), H. Folmut (Folmut, 2001), D. Khan (Khan, 1997).

According to the objectives of the International Group of Controlling (IGC), controlling is a key element of sustainable successful management. The main mission of the IGC is to develop, coordinate and promote the international unified concept and terminology of controlling; professions and roles of controllers as management partners, as well as the standards of qualifications of controllers and managers.

In the research S.O. Khailuk (Khailuk, 2005) carried out a comparative analysis of the use of controlling system in the management of enterprises of different countries on the following factors: the most used control functions, controlling methods, industry affiliation and the scope of activity of controlling companies, size of enterprise and type of controlling. 
Some interest from the standpoint of research in assessing the importance of various aspects of controlling is a research W. Becker, B. Baltzer and P. Urlich (Becker et al., 2011), in which are given basic advices on how controlling could or should develop in the present future in order to become or stay an independent branch, namely: in addition to the large enterprises focusing on controlling research, additional research is needed small and medium-sized enterprises; in order to gain greater international importance, German controlling research must become more empirical; controlling publications by German scholars must become more international themselves, that is to be written in English language [4, p. 52].

T. Vuko and I. Ojvan (Vuko et al., 2013) determine that «controlling function as a separate department contributes business efficiency trough ensuring transparency of business result and business processes...controlling realizes its purpose by coordinating and integrating business functions and by providing information for ensuring the rationality of executive actions, particularly concerning planning and monitoring» [32, p. 44, 51].

According to research results of R. Zamecnik and R. Rajnoha (Zamecnik et al., 2015) defined that «between the use of the concept of Controlling and Business Performance is strong statistically significant dependence, companies make higher performance in groups ROE» [34, p. 775]. Similar studies and conclusions are made in the work T.T. Vuko and I. Ojvan (Vuko et al., 2013).

Thereby controlling creates an effective management system based on the formation of the information needed to manage and make optimal management decisions, defines the purpose and monitoring of each management process (planning, accounting, information and analytical support, analysis, organization, motivation, coordination, control). In this context, the main purpose of controlling is to continuously improve the efficiency of the enterprise, achieved through the use of appropriate methods.

In the research S.O. Khailuk (Khailuk, 2005) determined that «Controlling is based on three components: economic system, management, information system. The presence of these three components is confirmed by the historical stages of controlling development, during which the priorities and orientations of the concept changed: in the 1930s it was a system of accounting; in the 1970s and 1980s, the management information system, in our time, the management system» [12, p. 37]. 
Implementation of controlling on port sector enterprises is covered in works by M.Yu. Artamonova (Artamonova, 2010) - represented the composition of the controlling service and its work, for assessing the effectiveness of which considered controlling tools that allow the management of the fleet of reloading equipment; V.A. Budnik and Ye.L. Shkurko (Budnik et al., 2014) - the feasibility of introducing instruments for controlling tariffs for cargo handling in seaports is substantiated, which consists in determining the reasonable amount of the discount from the value of currently operating tariffs for loading and unloading port services; I.Yu. Potay (Potay, 2015) - justified the expediency of using the controlling system in the management of Ukrainian seaports; N.V. Ryabovolenko (Ryabovolenko, 2017) - the application of a methodical system of controlling for the introduction of competitive, economically justified rates of port dues, systematization of expenses of enterprises of port activity compensated by port fees to unify the calculations of their justified rates; S.V. Oneshko and I.I. Popov (Oneshko et al., 2019) - features of construction of the system of economic safety management of port enterprises are considered, and is proposed an approach to the estimation of the level of economic security on the basis of the controlling system, which includes assessment of the status: market, finance, material resources, calculations and innovations.

The analysis of scientific researches in the direction of implementation and realization of the system of controlling on the enterprises allowed to determine that in scientific works the method of estimating the effect and effectiveness from the introduction of controlling is rather limited, there are no practical recommendations for the implementation of controlling taking into account the specific features of the enterprises, in particular, enterprises of the port sector, there are no scientifically substantiated theoretical-methodical and organizational measures for the formation and implementation of the control system. In addition, at present, there is inefficiency and discrepancy of methodological approaches to assessing the implementation of the control system in the direction of adaptation to the use of modern economic conditions and market requirements related to the conditions of their operation for Ukrainian enterprises. Thereby, research in this direction needs to be improved. 


\section{Advantages and disadvantages of introducing the controlling system at enterprise}

The treatment of the concept of «controlling» in literary sources is ambiguous and has fundamental differences. The ambiguity in the definition of controlling may be explained by the fact that its development took place over a long period of time during which it was modified, as well as the difference in models with respect to theoretical research and practical use.

In the researched V.S. Rudnitsky (Rudnitsky, 2012) found that «The notion of «controlling» appeared in economic literature in the first half of the eighties of the twentieth century in western Europe. The main idea of controlling is the construction of a logical system, which, thanks to an ordered combination of various structural elements of the enterprise, taking a direct part in its economic activities, expressed in financial, economic, organizational and technical spheres, will help management in making more effective management decisions in the area of the operational (operational) and strategic activities» [27, p. 221]. Variety of approaches to the interpretation of the concept of «controlling» and the definition of this category at the legislative level allows it to be interpreted depending on the industry, form of ownership, organizational structure and peculiarities of the use of analysis and forecasting methods.

Foreign practice shows the effectiveness of the implementation of controlling on the enterprise. Thereby, in the US, the controlling service is directed in the financial direction: budgeting, insurance management, tax administration. Germany focuses on cost management and planning.

In the research S.O. Khailuk (Khailuk, 2005) states that «The effectiveness of the introduction of control methods is confirmed not only by highly developed countries, such as the United States, Great Britain or Germany, but also the countries of the post-Soviet area. For example, growing competition and the entry of Poland into the EU stimulates the interest of Polish entrepreneurs in planning, analyzing deviations and budgeting. An interesting point in their practice is that most of the Polish companies use the Excel toolkit as an information provision tool, rather than special software products. A similar situation takes place in Germany» [12, p. 39]. Whereas, I.Yu. Potay (Potay, 2015) noted that «At present time, Ukraine has developed all the prerequisites for the formation and implementation of controlling in view of the fact that owners of majority of companies have become con- 
trolling stakes. Their main task was not only the expansion of business, but also effective management of property, in order to increase its profitability and investment attractiveness» [26, p. 113].

The positive and negative consequences of the implementation of controlling system are quite actively discussed in the scientific literature: A. Benkovska, O.I. Safarov (Safarov, 2008), Z. Kral and A. Zablotskaya-Kluchka (Benkovska et al., 2008), O.B. Hrebets (Hrebets, 2009), M.Yu. Artamonova (Artamonova, 2010), V.L. Zagorudko and K.S. Trofimova (Zagorudko et al., 2012). Determine the most significant advantages and disadvantages of introducing controlling, which are summarized in Figure 1.

The operating companies already have planning and economic departments, accounting department, financial department, sales department, logistics department, which partly perform the functions of controlling service. However, their function does not include ensuring quality coordination and adaptation of plans and objectives of the enterprise.

In general, the controlling is one of the most effective business systems, and the controlling system helps the company not only to define the objectives, principles and methods of management, but also the means of their implementation. The work of this service is aimed at fulfilling not only current plans, but also the prospects for enterprise development. In a certain sense, controlling can be considered as management of enterprise profits, and its implementation will more clearly monitor the performance of the enterprise and its structural units. Successful implementation of controlling is impossible without the participation of the management, while employees must also be aware of the significance of the introduction of strategic and operational controlling, which is based on the relevant information that is necessary for the acceptance of optimal managerial decisions on various aspects of the enterprise.

World experience proves the active introduction of controlling on enterprises not only large but also medium and small enterprises.

The research D. Špac and L. Mošnja-Škare (Špac et al., 2009) showed that «in companies with more than 100 employees the controlling tasks were performed by the finance and accounting department. In companies with 100-500 employees the controlling department was directly responsible to the finance and accounting managers (linear structure) in 50\% of cases. In companies with more than 500 employees controlling was estab- 


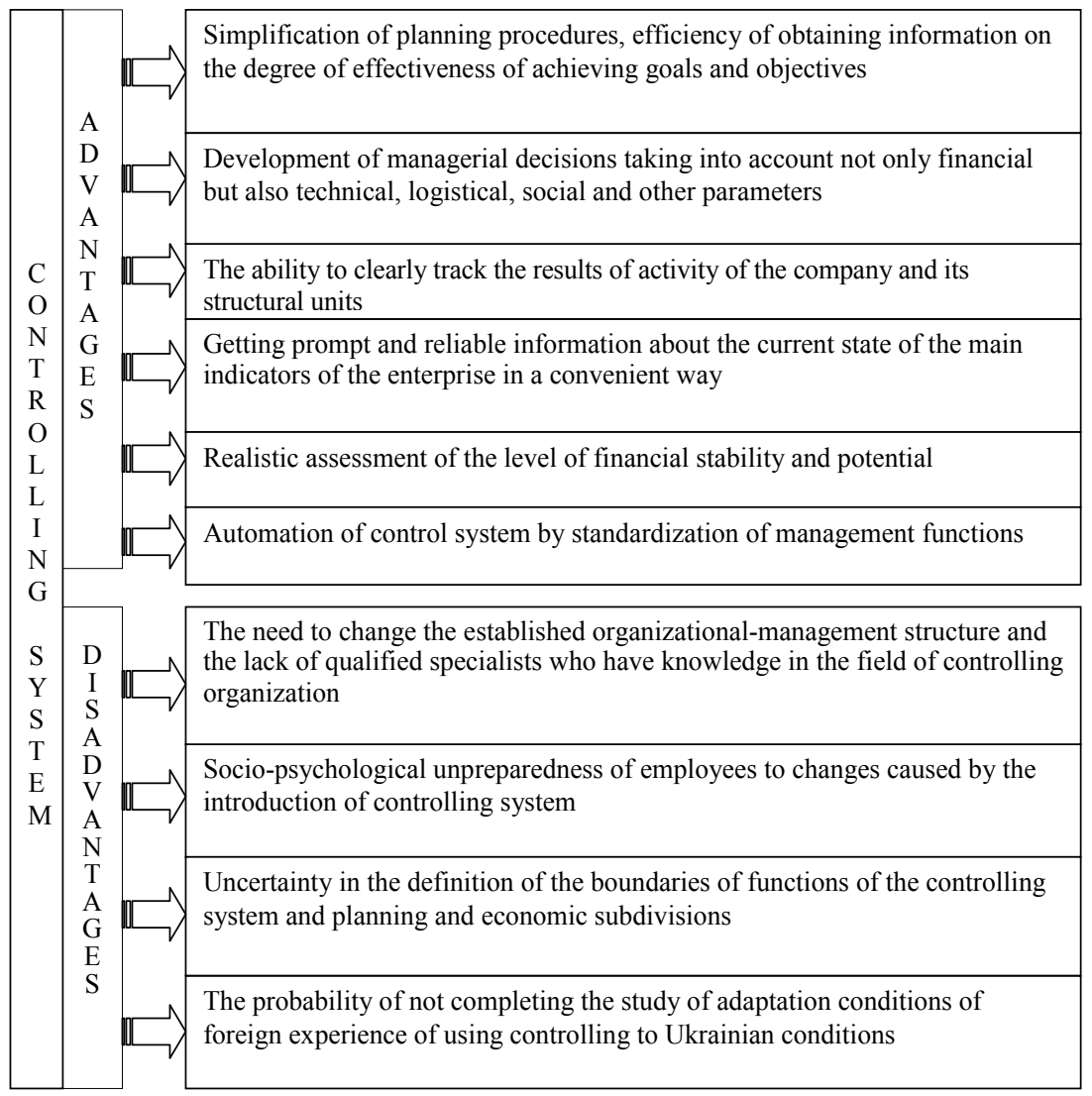

\section{Figure 1. The main advantages and disadvantages of introducing the controlling system at enterprise}

Source: compiled by the authors

lished like an independent department. Similar results could be found not only in Switzerland and Austria but in the companies of all developed European countries» [31, p. 67].

The research T. Vuko and I. Ojvan (Vuko et al., 2013) concerning the use of controlling units in Croatian companies made it possible to draw the following conclusion: «Initial analysis of the results shows that $30 \mathrm{com}$ - 
panies $(76,9 \%)$ have controlling department, while 9 companies $(23,1 \%)$ don't have controlling department. The most important reasons for establishing controlling department were global economic and technological changes in contemporary business environment. Controlling department is most frequently established in financial sector. According to the ownership structure, almost all analyzed foreign companies have controlling department (13 out of 14 companies), in contrast to $68 \%$ (17 out of 25 ) of domestic companies that have controlling department. The most frequent number of employees in controlling department is between 4 and 6» [32, p. 48].

Analysis of the use of controlling departments by Slovak enterprises conducted by R. Zamecnik and R. Rajnoha (Zamecnik et al., 2015) has determined that the number of enterprises with a positive ROE level is $10 \%$ higher in companies where management is carried out using controlling techniques.

\section{Implementation of the controlling system in the functioning of the stevedoring company}

The process of controlling development in Ukraine is very slow. The analysis of organizational structures, executed using data from the official website of the Ministry of Infrastructure of Ukraine, determined that the controlling department is absent from all state stevedoring companies (Table 1).

According to the results of the analysis of organizational structures of state stevedoring companies of Ukraine, it was established that there is no controlling department at all enterprises. In addition, there are no control units in most enterprises. Thus, the emphasis on asset management has been made on the SE «Mykolaiv SCP», the control and audit department is available only at two enterprises: SE «Mariupol SCP» and SE «Odesa SCP», audit department at SE «SCP Chornomorsk» and SE «Mariupol SCP». The largest presence of control units is observed at SE «Mariupol SCP» (control and audit department, investment and operational control department, control and asset management department, audit department).

Audit reports on the results of the state financial audit of state stevedoring companies, published on the official site of the State Audit Service of Ukraine, confirm the fact of insufficient organizational aspect of control. Thus, «due to lack of control and non-use by the Company's management 
of measures to comply with the legislation, timely payment for the received goods/works/services, etc., and non-performance of contractual obligations under concluded contracts, the enterprise incurred excessive expenses for the payment of penalties (fines, penalties, penalties) for the total amount of 212.0 thousand UAH (in the 2 nd half of 2016 - 20.4 thousand UAH, in 2017 - 191.6 thousand UAH)» [19, p. 65].

Table 1

\section{Availability of control department in SE stevedoring companies} of Ukraine

\begin{tabular}{|c|c|c|c|c|}
\hline State Stevedoring Companies & 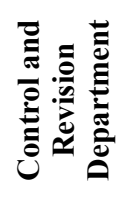 & 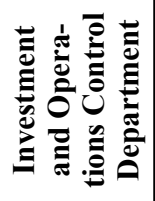 & 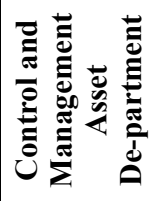 & 竞 \\
\hline $\begin{array}{l}\text { SE «Berdyansk Sea Commercial } \\
\text { Port (SCP)» }\end{array}$ & - & - & - & - \\
\hline SE «Bilhorod-Dnistrovsk SCP» & - & - & - & - \\
\hline SE «Izmail SCP» & - & - & - & - \\
\hline SE «Mariupol SCP» & + & + & - & + \\
\hline SE «Mykolayiv SCP» & - & - & + & - \\
\hline SE « SCP Ust-Dunajsk» & - & - & - & - \\
\hline SE « SCP Chornomorsk» & - & - & - & + \\
\hline $\mathrm{SE} \ll$ Odesa SCP» & + & - & - & - \\
\hline $\mathrm{SE} «$ Reni SCP» & - & - & - & - \\
\hline $\mathrm{SE} «$ Skadovsk $\mathrm{SCP} »$ & - & - & - & - \\
\hline $\mathrm{SE}$ «Stevedoring company «Olvia» & - & - & - & - \\
\hline $\mathrm{SE} «$ Kherson SCP» & - & - & - & - \\
\hline $\mathrm{SE}$ «SCP «Yuzhny» & - & - & - & - \\
\hline
\end{tabular}

Source: compiled by the authors on the basis of Financial plans and reports of water transport of Ukraine (2018)

The positive point is that in 2018 the SE «Odesa SCP» according to the financial plan, which is published on the official site of the Ministry of Infrastructure of Ukraine, is planning to implement capital investments for the purchase of software for unified management accounting in terms of cost optimization for maintenance of automated information systems of the enter- 
prise and the organization of conditions for the implementation of a single, unified platform for enterprise resource planning, automation of management and business processes. This software is based on the application modular structure and, besides other modules, includes the controlling module that provides accounting for costs and profits of the enterprise and includes: cost accounting for orders, accounting for project costs, cost calculation, profit control, production accounting, and controlling enterprise activity.

If controlling is regarded as a management system for the profit of the enterprise, then the considerable interest in determining the financial results in the form of profit. Recently, there has been a tendency towards a reduction in the financial performance of state stevedoring companies in Ukraine (Figure 2).

According to Fig. 2 it is possible to conclude that there isa significant decrease in profits (by 74.4\%) in 2018 for all state stevedoring companies. The increase in profits occurred only in the SE «Mykolayiv SCP» - by $41.8 \%$ and SE «Odesa SCP» - by $22.3 \%$; for all other enterprises there is a tendency to decrease the financial result in the form of profit. Especially fast decreased the profit of SE «SCP Chornomorsk» $(88.3 \%)$, SE «Mariupol SCP» (by 68.8\%) and SE «SCP «Yuzhny» (64.3\%) decreased especially fast. Lossy enterprises in 2017 were SE «Bilgorod-Dnistrovsk $\mathrm{SCP} », \mathrm{SE}$ «Reni SCP», SE «Skadovsk SCP» and SE «Kherson SCP», and in 2018 they joined the SE «Berdyansk SCP» and SE « SCP Ust-Dunajsk».

Along with the decrease in the size of the profit of state stevedoring companies in the research of M.O. Boiko (Boiko, 2018) concluded that «private stevedoring companies are becoming more and more weighty positions with each passing year, their size and share in the total volume of cargo processing is constantly increasing. In the structure of cargo handling, stevedoring companies of Ukraine take a dominant position in private stevedoring companies, with their share constantly increasing - from $66.1 \%$ in 2015 to $73.8 \%$ in 2017 » [6, p. 138].

I.Yu. Potay (Potay, 2015) confirms that «at the present stage, the most im-portant task of sea ports is to attract freight traffic and increase the volume of cargo transhipment. Due to the fact that the range of goods is constantly changing and the weight of one cargo space increases, special requirements are provided to the fleet of reloading equipment, which should consist of powerful and versatile equipment» [26, p. 113]. 


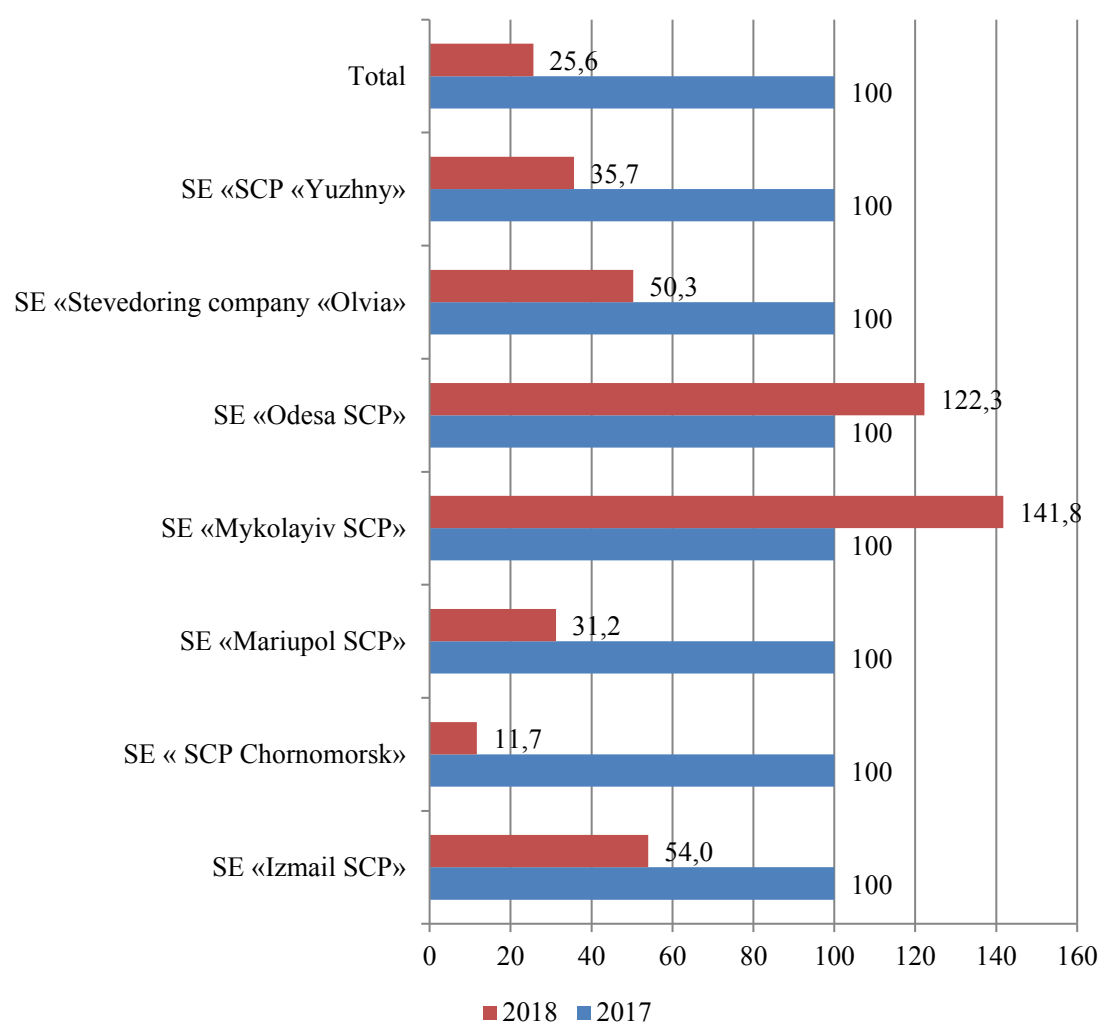

Figure 2. Dynamics of profit of state port operators of Ukraine, \% Source: compiled by the authors on the basis of Financial plans and reports of water transport of Ukraine

Structural changes in cargo turnover in comparison with the actual and planned indicators that are typical for state stevedoring companies of Ukraine take place in the direction of processing of less attractive cargo, and as a result, even with the general increase in volumes of cargo processing, the profit from processing of goods increases not so fast rates as the volume of processing or an increase in profit is due to an increase in the chord rate. Besides, the negative tendency of development of port activity in Ukraine is a fall in transit traffic. To keep traffic and attract new ones, stevedoring 
companies must increase their competitiveness. Along with this, considerable progress can be made in working with private stevedoring companies that have shown interest in investing in Ukrainian seaports.

In connection with the foregoing, of great importance the search for new methods of control, determined by M.Yu. Artamonova (Artamonova, 2010): «A tool that integrates accounting, control, planning into a single self-governing system, which clearly defines the goals of the enterprise, management principles and methods for their implementation, may be the controlling system. For its effective implementation in the seaport, an appropriate specialized service should be set up that provides system collection, processing and analysis of information across all port departments, defines it in accordance with the adopted development strategy, prepares constructive proposals for guidance on the effective resolution of the problems that have arisen. On this basis, the quality of management is greatly improved» [1, p. 132].

According to the results of the analysis of financial statements of state stevedoring companies of Ukraine, audit reports on implementation of financial plans, the reasons for the necessity of implementation of controlling on port enterprises were formulated and systematized:

- increasing the instability of the environment and the need for continuous tracking and increasing the speed of reaction to its changes, while respecting the increased flexibility of management decisions;

- the existence of shortcomings in the efficiency of cost management as a risk factor for additional and unproductive costs of financial and material resources, the need to shift the emphasis from past control to the analysis of the future;

- depreciation of the main productive assets and inefficiency of investments as a risk factor for the impairment of investments and lost profits and, as a consequence, the likelihood of a risk of loss of investment attractiveness and competitiveness;

- ineffective use of fixed assets and other non-current assets, which leads to insufficient cost optimization in the form of depreciation, occurrence of unproductive costs and lack of revenue;

- long distraction from the circulation of financial resources into accounts receivable, which is a risk factor for lost profits, impairment of receivables due to inflationary processes; 
- the lack of tools for selecting relevant information in the presence of a large amount of information necessary to make managerial decisions as a risk factor for untimely management decisions, requiring the construction of a special system of information provision and database generation in MS Excel;

- insufficient internal control and inconsistency of accounting policy with the requirements of the current legislation, which entails the risk of unreliability of information about the results of its activities.

The instability of the environment is mainly due to the decrease in the volumes of cargo handling in some seaports of Ukraine due to the complex foreign-policy relations between Ukraine and the Russian Federation, the reorientation of the transit of Russian coal to the seaports of Romania, Bulgaria, Turkey and Croatia; the reorientation of the transit of petroleum products from Belarus to the ports of the Baltic, Russian petroleum products and liquefied hydrocarbons of Russian origin to the ports of Russia in connection with the decision taken by the Russian Federation to load capacities of its own ports. Increasing the response rate to changes in the environment should occur simultaneously with the flexibility to make managerial decisions - an opportunity to adjust the management decision with the emergence of new circumstances financial and economic activity.

The risk of additional and unproductive costs of financial and material re-sources is directly related to the existence of deficiencies in the efficiency of their management. In this way, the current tendency to reduce turnover and profitability shows the likelihood of an inefficient organization of production management. In this direction it is necessary to shift the emphasis from the control of the past to the analysis of the future, which will not only record the facts that the company is not able to influence, but also predict, minimize and level the risk operations.

The problem of high depreciation of the main production facilities of sea ports of Ukraine is quite acute in front of Ukraine's seaports. In this way, in the work of Patynsky (Patynsky, 2012), was noted that «in modern conditions, the service life of berthing facilities in Ukrainian ports is 30-40 years, exceeding the deadline or approaching it». According to the Ukrainian Sea Ports Authority (USPA), depreciation of the port infrastructure is one of the factors restraining the increase in traffic through Ukrainian seaports. On the balance of the Administration of seaports, there are 263 berths with a total 
length of $43 \mathrm{~km}, 16$ berths in this area are completely decommissioned, 31 are unserviceable, and 48 are in need of major repairs. According to the conclusions made by L.V. Shiryaeva, S.V. Oneshko and G.A. Kuznetsova (Shiryaeva et al., 2018): «at the present time there are problems connected with the fact that the majority of hydrotechnical structures of sea ports of Ukraine are designed using unconventional technical solutions, works in complex engineering and geological conditions and is intensively exploited for a long period of time. As a result, ports may be at risk in the part concerning the technical condition of the mooring front» [30, p. 99].

This situation affects the likelihood of a risk of loss of investment attractiveness and competitiveness of Ukrainian sea ports, leads to an increase unproductive costs and insufficient of revenue.

Problematic issues related to the ineffective use of fixed assets include: the mismatch of the fleet of reloading equipment and its obsolete nature, the mismatch of the reliability of the port equipment and its optimum terms of service, the difference between the depreciation recorded in accounting and depreciation, which reflects the actual technical condition of the main funds.

The study of I.Yu. Potay (Potay, 2015) on controlling strategic planning of the development of sea ports of Ukraine indicates the existence of high maintenance costs for maintenance of the technical reloading base and states: "The decision of the problem of determining the optimal fleet of reloading equipment for this cargo flow will directly affect the formation of operational articles costs, especially such as repairs, fuel and electricity, depreciation charges». This fact is confirmed by studies M.Yu. Artamonova (Artamonova, 2010): «the right choice of port technology for the development of freight traffic and its use in reasonable operating modes that are responsible for the development of freight traffic, but do not exceed the permissible loads in cars, will provide a minimum operating costs for transhipment, increase the return on assets and the efficiency of capital investments in the purchase of cars» [26, p. 134].

Distraction from the circulation of financial resources into receivables should be considered from the position of diminishing value of funds in time due to the effects of inflationary processes. From the position of controlling receivables, it is possible to propose measures for its collection, for example, taking into account penalties, $3 \%$ annual and inflationary expenses for the entire period of debtors' violation of monetary obligations. 
Necessity for the selection of relevant information in the case of management decisions is actively discussed by scholars D. Caplan (Caplan, 2006), S.V. Oneshko (Oneshko, 2014), R. Osmani (Osmani, 2017). The importance of this information is explained by the research carried out by Panas, Ya.V. (Panas, 2017): «The creation of an effective information field that arises in the complex application of controlling tools helps in the adoption of managerial decisions designed to promote the development of enterprises in the difficult competitive conditions of the modern technological structure» [24, p. 201]. In turn, «the separation of relevant information when making managerial decisions in the transport industry gives the opportunity to respond quickly to various aspects of activity, to freely navigate in a constantly changing environment, to determine internal reserves to reduce costs» $[21, \mathrm{p} .151]$.

The risk of direct loss of profit is directly related to the lack of organization of internal control and inconsistency of accounting policy of the enterprise with the requirements of the current legislation. The consequence of this is the unreliability of displaying information about the results of activities and the lack of profit as a result of failure to implement measures to eliminate gaps in accounting estimates that arise as a result of the appearance of new information or the development of events. For example, an estimate may be needed to determine the amount of bad debt, inventory aging, the fair value of financial assets or financial liabilities, useful lives and warranty obligations.

Thereby, the introduction of controlling system on the port enterprises is directly related to the possibility of having lost profit. According to Art. 22 of the Civil Code of Ukraine «lost profits - revenues that a person could actually receive in normal circumstances, if its right was not violated» [9].

Examples of lost revenue due to ineffective management decisions, which were reflected in the results of the financial audit conducted by the State Audit Office of Ukraine: in 2017 in the SE «Odesa Sea Commercial Port» - 1,097.54 thousand UAH, in the SE «Sea Commercial Port» Yuzhny» - 254.79 thousand UAH, in SE» Sea Commercial Port «Chernomorsk» -95.49 thousand UAH.

Implementation of controlling system in the work of the stevedoring company can be accomplished by implementing the steps given in Figure 3. 


\section{Chapter «Economic sciences»}

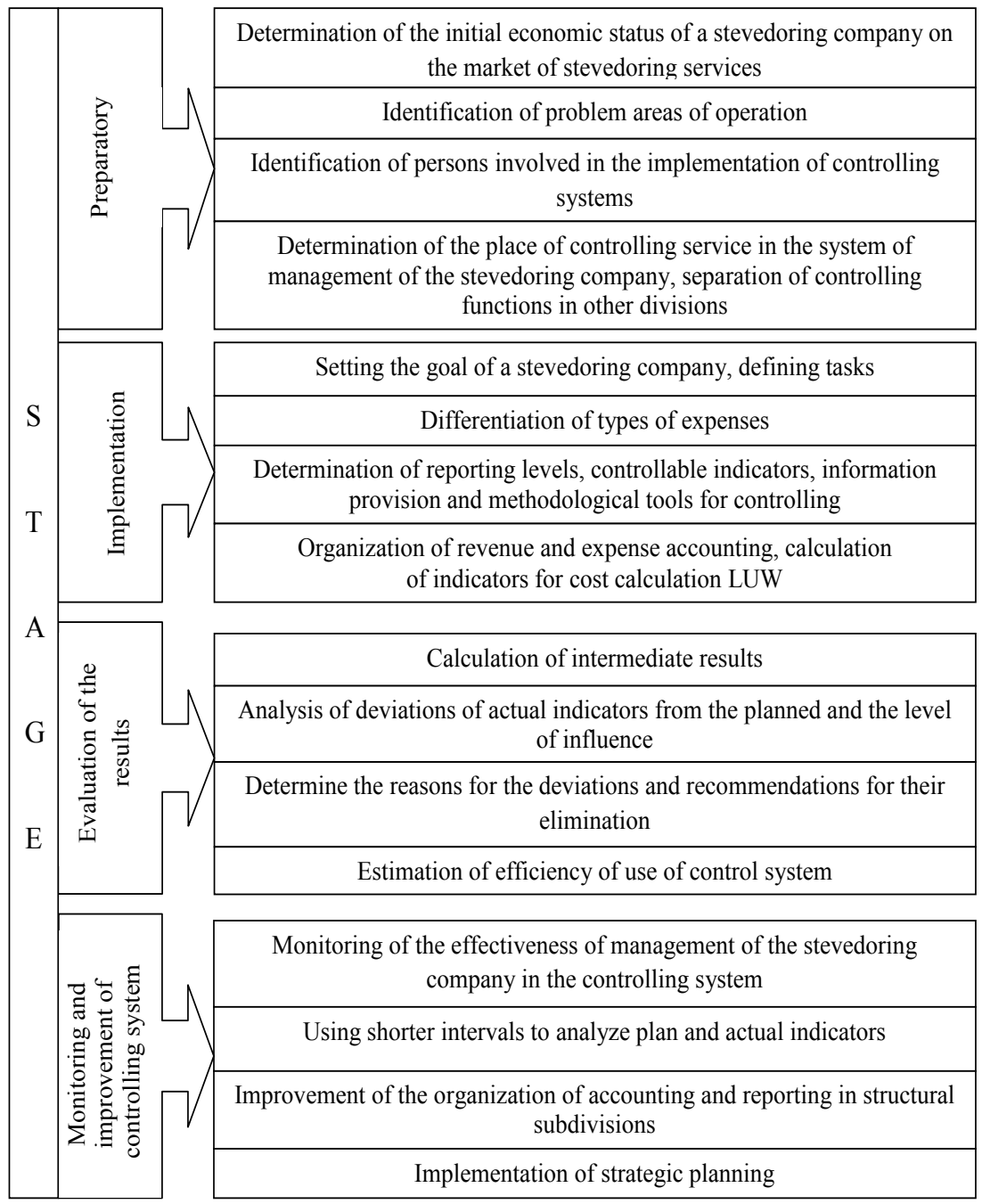

Figure 3. Organizational and economic approach to the implementation of controlling system in the work of the stevedoring company

Sources: developed by the authors 
At the preparatory stage, in determining the initial economic status of the stevedoring company in the market of stevedoring services, are considered indicators of volumes of cargo flows, cargo turnover and cargo processing (by types of cargo and cargo flows) in dynamics, the share of the market, competitive analysis of tariff rates are considered. A separate block analyzes the trends in the size of the financial result and performance indicators, which allows you to identify the problem areas of business, which need to pay attention from positions of successful long-term operation of the stevedoring company. At this stage, the list of persons involved in the implementation of controlling systems includes specialists in the technical, technological, operational, financial and information support of the operation of the stevedoring company. In the future, the place of the controlling service in the system of management of the stevedoring company, its variant of the organization (association with one of the departments of financial and economic services of the enterprise or separation of the department which is directly subordinated to the head) is determined. At the same time, the creation of an overly complex structure should be avoided.

Given the existence of control functions in other units of the stevedoring company, it is necessary to coordinate these functions with the separation of competences of specialists of different levels, who develop methodological support for managerial decisions and timely inform the leadership of the stevedoring company about the solutions developed. This direction is labour-consuming and involves the merger of management processes of various areas of the company's activities.

At the stage of implementation of controlling system, the strategic goal of the stevedoring company is primarily determined (increase of cargo turnover, increase of efficiency of utilization of available capacities, development of promising territories with the creation of the corresponding berthing line, expansion of throughput capacity, improvement of service, provision of optimal logistics of cargoes, etc.). On the basis of the strategic goal, the tasks are determined (increase of competitiveness, loading of production capacities, infrastructure development, optimization of tariff rates, rational use of resources, use of innovative technologies of loading and unloading works, etc.).

In the future, for the organization of the work of controlling system it is necessary to differentiate the types of costs, with special emphasis on operating costs (fuel and electricity, repair of reloading equipment, salaries 
of workers directly employed in the LUW, maintenance of reloading equipment, support work on the provision of reloading operations, deductions for social security, depreciation deductions, etc.).

The definition of reporting levels includes the development of a second level of reporting (managerial aspect) with the definition of controlled indicators that the controlling service will check. At the same time, an important step is to determination of periodicity of control, because different indicators do not have the same effect on the size of the financial result. So, from the standpoint of essentiality, the main criterion is the impact on the size of profit. For example, the change in electricity tariffs towards the increase will have a more significant effect on the amount of profit than the increase in the cost of office supplies for the administration. As part of controlled indicators, special attention is paid not to financial indicators: customer satisfaction, the number and quality of education, communication and continuity of operational business processes, etc.

Determination of information provision and methodical controlling tools is the main system of communication within the enterprise and is considered as a system of information management support. In general, are distinguished general economic (observation, comparison, grouping, complex and trend analysis, synthesis, systematization, forecasting) and specific (functional-cost analysis, analysis of the break-even point, ABC-analysis, $\mathrm{XYZ}$-analysis, zero-basis-budgeting) methods. In reality, stevedoring companies are faced with problems of determining the break-even and optimal volume of cargo turnover, an adequate assessment of the impact of the size and structure of the cost of profits, achieving maximum profit, and optimizing the size of fixed costs. In this case, the use of break-even analysis becomes important, which allows you to find the most advantageous combination of variable costs per unit of constant costs, prices, and volume of production.

Execution of the previous components of the implementation phase is completed by organizing the accounting of revenues, expenses and computation of indicators for calculation. The main source of funds for the reimbursement of the costs of a stevedore company is the proceeds from the sale of works (services), which is formed from net revenue from sales, other operating revenue, other financial revenue (interest on deposit accounts) and other revenue. In turn, costs include: cost of implementation, admin- 
istrative costs, sales costs, other operating expenses, financial expenses, other costs, expenses on revenue tax. Generally speaking, the traditional accounting system for the operating company has already taken place, and in relation to the organization for the needs of the controlling service, there are some features that are expressed in the methodological feasibility of the process of preparing management decisions and reporting, reflecting the results of these decisions, as well as their timeliness and consistency between functional units.

At the evaluation stage, intermediate results are calculated; an analysis of the deviations of the actual indicators from the plans and the level of influence is conducted. The results of calculations are estimated:

- general achievement of the results of activity;

- deviations (savings or over expenditure) in terms of expenses items and their impact on the financial result;

- indicators that require a more detailed analysis, such as factor analysis.

Further analysis needs to be supplemented by an analysis of the causes and effects of savings or over-expenditures, which will allow you to identify suggestions for improving the situation, develop or adjust the plan of measures.

An important value is the assessment of the results of financial and economic activity after the introduction of controlling system on the enterprise. Existing approaches of scientists (Artamonova, 2014; Potay, 2015) in this direction are:

- the annual size of the direct result is calculated as the sum of the obviated current costs after controlling introduction and is the constant during all years of the controlling use;

- assessment of the efficiency of the use of controlling system in the management of the seaport can be made on the indicator of economic effect:

$$
\mathrm{EE}_{\mathrm{SMS}}=\sum_{\mathrm{i}=1}^{\mathrm{n}} \mathrm{R}_{\text {operating.i }}-\sum_{\mathrm{i}=1}^{\mathrm{n}} \mathrm{R}_{\text {operating.i }}^{\prime}>0 \text {, }
$$

where EESMS - economic efficiency of use in the management of the seaport controlling system;

$\sum_{i=1}^{n} R_{\text {operating.i }}$ - operational costs of the port before the introduction of controlling;

$\sum_{i=1}^{\mathrm{n}} \mathrm{R}_{\text {operating. }}-$ operational costs of the port, obtained using the controlling system [2, c. $23 ; 26$, c. 115]. 
When the positive value of the economic effect indicator is used, the controlling system in the management of the seaport is effective.

At the stage of monitoring the effectiveness of management of the stevedoring company in the controlling system, it is necessary to identify the responsible controller and its functional responsibilities, among which the following must be present:

- assessment of the degree of achievement of the goal, the establishment of the tolerable limits of deviations from the parameters given;

- tracking and analysis of trends, deviations from forecast indicators, factors of influence on deviations, estimation and interpretation of deviations, systematization of data in order to identify positive and negative trends in the company's work;

- coordination of goals of different levels, means and methods of their implementation in order to maximize achieve the ultimate goal of the company.

In the direction of improving the operation of controlling system, it is possible to determine:

- use of shorter intervals for the analysis of planned and actual indicators - the transition from the annual, quarterly, monthly interval of analysis to almost daily, which requires the improvement of the existing information system at the enterprise and the generation of a database of all subordinate indicators in MS Excel;

- improvement of the organization of accounting and reporting in structural units - automation of control functions, application of methods of modeling, forecasting and optimization, unification of reporting of the second level, use of a single access network to the controlled indicators of the relevant officials;

- implementation of strategic planning - is achieved by coordinating and controlling income and expenditure, assessing the impact of their level on the indicators of the company in terms of qualitative and quantitative parameters, as well as timely impact on their magnitude.

In general, the controlling system can be used for the enterprise as a whole, its separate units, sections of economic processes and business operations. The main goal of implementing controlling in stevedoring companies is to ensure profitable operation in accordance with strategic goals and to ensure the adoption of management decisions to resolve the internal tasks of managing a stevedoring company. 


\section{Conclusions}

The systematization of scientific research has shown the need for the introduction of controlling in the management system of enterprises of the port sector, due to the following main reasons: increased instability of the environment and the need for continuous tracking and increase the speed of reaction to its changes; the existence of disadvantages in terms of cost-effectiveness; significant depreciation of the main productive assets and inefficiency of investments; long distraction from the circulation of financial resources into accounts receivable; lack of tools for selecting relevant information; insufficient internal control and inconsistency of accounting policy with the requirements of the current legislation. The research proposes an organizational-economic approach to the introduction of controlling in stevedoring companies, which takes into account the specifics of their activities and current trends in development. The obtained results deepen and develop the conceptual foundations of the controlling system at the enterprise and can serve as a basis for further research in this area, in particular, the development of a methodology and tools for assessing economic efficiency and the effect of introducing controlling on enterprises of the port sector. The practical significance of the research carried out is that the main theoretical conclusions and methodological provisions are brought to the level of concrete practical recommendations and can be used in the activities of port enterprises to improve the efficiency of functioning.

\section{References:}

1. Artamonova, M.Yu. (2010). Methods for evaluating the performance of the controlling system in seaports. Bulletin of the State University of Maritime and River Fleet name Admiral S.O. Makarova, 4, 131-136.

2. Artamonova, M.Yu. (2014). Seaport management using the controlling system. Thesis abstract of Ph.D., 28. Retrieved from: http://economy-lib.com/ disser/592283/a\#?page $=1$

3. Becker, W. (1990). Funktionsprinzipien des Controlling. Zeitschrift fuer Betriebswirtschaft, 60, 295-318.

4. Becker, W., Baltzer, B., \& Urlich, P. (2011). Controlling as a science in Germany - Retrospective, Status Quo and Outluk. Singidunum Revija, 8(2), 40-54.

5. Benkovska, A., Kral, Z., \& Zablotskaya-Kluchka A. (2008). Evaluation of results and deficiencies of control in the light of empirical research. Problems of the theory and methodology of accounting, control and analysis, 3(12), 61-72.

6. Boiko, M.O. (2018). Modern trends in the development of Ukrainian stevedoring companies. Bulletin of the Economy of Transport and Industry, 63, 133-144. DOI: $10.18664 / 338.47: 338.45 . v \% v i \%$ i.141132 
7. Budnik, V.A., \& Shkurko, E.L. (2014). Controlling Tariffs for Transshipment of Cargoes at Ukrainian Sea Ports. Problems of the economy, 2, 100-107.

8. Caplan, D., (2006). Management Accounting Concepts and Techniques. Accounting and Law Faculty Books. 1, 309. Retrieved from: http://classes.bus. oregonstate.edu/fall-06/ba422/management $\% 20$ accounting $\% 20$ chapter $\% 203$.htm.

9. Civil Code of Ukraine. Retrieved from https://zakon.rada.gov.ua/laws/ show $/ 435-15$

10. Folmut, H.I. (2001). Tools for controlling from A to Z, M.: Finance and Statistics, 288.

11. Hrebets, O.B. (2009). Controlling as a modern management system. Economy and the state, 12, 71-72.

12. Khailuk, S.O. (2005). Foreign experience in using the controlling system in the financial management of enterprises. Bulletin of the Ukrainian Academy of Banking, 2(19), 36-41.

13. Khan, D., \& Hunenberg, X. (2005). Planning and Control: Cost-Oriented Controlling Concepts. M.: Finances and Statistics, 925.

14. Khan, D. (1997). Planning and Control: Controlling Concepts. M.: Finance and Statistics, 800.

15. Mayer, E. (1993). Controlling as a system of thinking and management. M.: Finance and Statistics, 96.

16. Mirchev, A., \& Kryvoruchko, L.B. (2013). Controlling effect on the economic security of Engineering enterprise conducting foreign Economic activity. Economic processes management, 1. Retrieved from: http://epm.fem.sumdu.edu.ua/ download/2013_1_8.pdf

17. Official website of International Group of Controlling. Retrieved from: https://www.igc-controlling.org/

18. Official website of Ministry of Infrastructure of Ukraine. Financial plans and reports of water transport. Retrieved from: http://mtu.gov.ua/timeline/Plani.html

19. Official website of State Audit Service of Ukraine. Retrieved from: http://www.dkrs.gov.ua/kru/uk/publish/article/136382;jsessionid=644F7211470 680C470B0EB6A6936A655.app1

20. Official website of Ukrainian Sea Ports Authority. Information material. Retrieved from: http://www.uspa.gov.ua/ru/press-tsentr/analitika/analitika-2017/ 15296-proekty-vetskagansa-kakie-prichaly-moderniziruet-i-postroit-ampu

21. Oneshko, S.V. (2014). Port operator costs management based on relevant information. Economic analysis, vol. 16, 2, 148-156.

22. Oneshko, S.V., \& Popov, I.I. (2019). Controlling the economic security of port enterprises. Bulletin of the Economy of Transport and Industry, 65, 39-51. DOI: $10.18664 / 338.47: 338.45 . v 0 v i 65 i .155861$

23. Osmani, $R$. (2017). Relevant information as a tool of managerial accounting research in companies of the polog region. ECOFORUM, vol. 6, 1. Retrieved from: http://www.ecoforumjournal.ro/index.php/eco/article/view/559

24. Panas, Ya.V. (2017). Model introduction of controlling innovation in the practice of managing industrial enterprises. Marketing and Innovation Management, 1, 193-204. DOI: http://doi.org/10.21272/mmi.2017.1-17 
25. Patynsky, V. (2012). The status of port hydrotechnical structures of Ukraine. Ports of Ukraine, 5(117). Retrieved from: https://ports.com.ua/articles/archive/ sostoyanie-portovykh-gidrotekhnicheskikh-sooruzheniy-ukrainy

26. Potay, I.Yu. (2015). Controlling Strategic Planning for the Development of Seaports of Ukraine. Collection of scientific works of the National University of Shipbuilding, 6(462), 109-118. DOI: 10.15589/jnn20150617

27. Rudnitsky, V.C. (2012). Types of modern controlling. Bulletin of the National University «Lviv Polytechnic», 722, 221-225.

28. Ryabovolenko, N.V. (2017). Controlling Port Fees at Seaports of Ukraine. Problems of Transport Economics, 14, 88-96. DOI: https://doi.org/10.15802/pte. v0i14.123872.

29. Safarov, O.I. (2008). Controlling Practice: What prevents the success of its implementation? Actual problems of the economy, 4, 27-31.

30. Shiryaeva, L.V., Oneshko, S.V., \& Kuznetsova, G.A. (2018). On the issue of increasing the efficiency of the use of hydraulic structures of port enterprises. Development of methods of management and management in transport, 4(65), 97-111. DOI: 10.31375/2226-1915-2018-4-97-111

31. Špac, D., \& Mošnja-Škare, L. (2009). Controlling in Transition Environments: Empirical Evidence from Croatia. South East European Journal of Economics and Business, 4(1), 63-80. DOI: 10.2478/v10033-009-0005-4

32. Vuko, T., \& Ojvan, I. (2013). Controlling and business efficiency. Croatian Operational Research Review (CRORR), 4, 44-52.

33. Zagorudko, V.L., \& Trofimova, K.S. (2012). Research of the main advantages of the organization of controlling system at domestic enterprises. Effective Economy, 4. Retrieved from: http://www.economy.nayka.com.ua/?op=1\&z=1083

34. Zamecnik, R., \& Rajnoha, R. (2015). Strategic business performance management on the base of controlling and managerial information support. Procedia Economics and Finance, 26, 769-776. 